Article

\title{
Is Green Marketing a Label for Ecotourism? The Romanian Experience
}

\author{
Puiu Nistoreanu ${ }^{1}$, Alina-Cerasela Aluculesei ${ }^{1,2, *(\mathbb{D})}$ and Daniel Avram ${ }^{1}$ \\ 1 Department of Tourism and Geography, Faculty of Business and Tourism (formerly Commerce), Bucharest \\ University of Economic Studies, București 010404, Romania; puiunistoreanu@yahoo.it (P.N.); \\ avram89@yahoo.com (D.A.) \\ 2 Institute for World Economy, Romanian Academy, Bucharest 050711, Romania \\ * Correspondence: alina.cerasela@iem.ro
}

Received: 19 July 2020; Accepted: 6 August 2020; Published: 8 August 2020

\begin{abstract}
The focus on sustainability represents the key to the tourism industry today. Green marketing was constantly on the agenda of local authorities and started to be a subject of interest for Academia too, but it was very little approached in the Eastern European countries, especially in the tourism studies. This article describes the presence of green marketing in Romanian ecotourism and its impact on tourist's perception. Due to its natural landscapes and tourist attractions, Romanian ecotourism can take advantage of green marketing practices and promote tourism products based on the new preference of the tourists for sustainable activities. However, there is a lack of legislative framework regarding green labeling that can effect in the long term the destination brand. The main objective of the present article is to give an overview image of the online presence of the Romanian ecotourist accommodation units that applied for the Eco-label provided by the ECO-Romania Association. The study describes how these establishments use green marketing practices and if their guests perceive the green image too. The methodology of the study consists of a qualitative analysis of the primary data obtained by the authors from the websites of ECO Romania Association, TripAdvisor platform and accommodation units. The results show a high interest of the accommodation units from the ecotourism field for green marketing practices which is also perceived by tourists. The tendency of tourism stakeholders to apply for an accreditation system provided by non-governmental organization instead of choosing a European accreditation shows the impact of such a national initiative and emphasizes the need to develop a legal framework for green ecotourism practices.
\end{abstract}

Keywords: green marketing; green tourism; green marketing in tourism; ecotourism; Romanian ecotourism

\section{Introduction}

The tourism industry is one of the most blamed in terms of damages to the natural environment, because of the overconsumption of natural resources like water, energy and raw materials for constructions. In this context, guests became more sensitive to environmental issues caused by tourism, so companies feel pressed to choose a more ethical way to do business, including green marketing practices [1]. Some units use the label "green hotel" to attract their potential customers as such an image is believed to retain their loyalty [2]. However, even if there is an interest from the stakeholders in tourism for green brands and there is evidence that especially young tourists are very concerned about the impact of the industry on the natural landscape [3], this concept is not fully understood and applied in tourist destinations [4]. In order to have success, a green orientation of marketing in hospitality should address the customers as a full green experience and engage them in eco-friendly actions $[5,6]$. 
This article represents an empiric study of the Romanian accommodation units from the ecotourism field that promote their offer as green. The authors intend to describe the online image of the units accredited by one of the Romanian associations in the field recognized at European level taking into account the current tendency of tourists to get information from online sources. The research is based on primary data obtained from ECO Romanian Association, the accommodation units' websites and TripAdvisor platform and gives a complex perspective about green practices, including the units' representative green strategy and the guests' perception. The study has a high degree of novelty, being the first study in the field that focuses on an Eastern European country that has an impressive ecotourism potential. The results give an overview perspective to the stakeholders in the field and represent a starting point for a more centralized accreditation process which involves green marketing practices, and that should become mandatory in Romania and other European countries.

\section{Literature Review}

\subsection{The Concept of Green Marketing}

The practice of green marketing represents a result of the increasing interest of consumers on sustainability [7] and put pressure on the companies to reconsider their business practices [8]. This attitude is typical, especially among young clients [9] that are very concerned about their green image [10] and became more and more common in Eastern European countries [11]. The tendency of the customers to be interested in green practices, also named as "environmentally friendly" became visible in the decade of the eighties [12], a time of sustained economic growth in post-industrial countries that also experienced a significant development of green organizations [13]. Since then, consumers have continuously become more responsible for their purchase behavior and started to choose companies and products accordingly [14].

Green marketing refers to specific practices that do not have a negative environmental impact. The concept is synonym with decreasing in use of the raw materials and energy and has as main background the natural resource-based view theory that refers to pollution prevention, product stewardship and sustainable development [15]. According to the American Marketing Association definition, green marketing may also describe the process to produce, promote or package products in a sustainable manner [16]. In the context of this behavior, consumers switch from a cost-oriented perspective to a more sustainable one [17]. Targeting customers that are sensitive to environmental issues represents an advantage for companies that have a wide range of marketing strategies. In this context, excluding this niche of customers can damage the company's image in the long term [18,19] "as green marketing philosophy and eco-orientation are related to competitiveness, environmental values and economic objectives" [20,21].

However, some enterprises do not adopt green marketing, despite the clear evidence that a green association with the brand have specific advantages. The reason for this consists in the green paradox which associates green practices with intangible aspects of the brand, such as reputation or staff environment than with profitability [22]. Consequently, even though there are more than 30 years since many structures have adopted green marketing, it remains specific only to some niches. Since individuals have more power than ever and can influence consumer behavior, the green label will become mainstream in the next decades. In this context, companies that have been reliant on their eco image shall adapt to the new trend in order to stay competitive [23] and to emphasize the understanding of the label by consumers, especially in the field of food [24].

Green market represents the mix of promotion and advertisement of services and products that have a minimum impact on the environment [25], how is the case of ecotourism. Using such marketing strategies is favorable for companies because they can show customers their interest in developing environmentally friendly products [26]. Green marketing has an increased influence on tourists behavior regarding the environment [27] and is also known as sustainable marketing, organic or ecological marketing, even though these terms apply to only some parts of the concept [28]. 


\subsection{The Link between Ecotourism and Green Marketing}

Taking into account the specific components of green marketing and the increasing interest of tourists to choose destinations connected with nature, the authors consider ecotourism the main form of tourism suitable for green promoting practices. In this regard, the authors focus their attention in this article describing the connection between ecotourism and green marketing.

Ecotourism assumes nature-based activities and has as main principles to mitigate the impact on the environment [29] and to have a wide range of benefits for the local community [30]. According to the definition of World Tourism Organization, it has the following characteristics: is designed for small groups and involves small and local businesses, has an important educational aspect, with a high focus on decreasing the negative impact on the environment, including the communities and supports the socio-economic development of the natural area [31,32]. "In the green economy, ecotourism marketing plays an important role, by providing to consumers essential information about the degree of responsibility assigned to visited areas, which also aims to lead to the highest degree of ecotourists demand satisfaction" [33].

Ecotourism, as agritourism, can be considered a real alternative of agriculture for the local people living in rural areas and a valuable tool to improve their quality of life [34], proposing more sustainable practices, like organic farming, preservation of cultural customs and traditions and involvement of community members in tourism activities [35]. However, apart from its image of win-win idea and the fact it involves minimal negative impacts on the environment, ecotourism can also transform in mass tourism [36], due to the increasing pressure on wildlands and wildlife [37]. In order to mitigate this risk, the first initiatives that a local community can adopt, refer to making available guidebooks and signs with actual information, providing trained guides at the destination [38] and adopting other green initiatives.

In this context, ecotourism can be considered "green" not only through its activities but also through the engagement of green marketing strategies, including aspects like active pursuits; creative industries; celebrations of the past; nature tourism activities; festivals and events; and accommodation [39]. Ecotourism is often presented as a part of the solution for the problems of mass tourism and prevents tourism development in an unstainable way that is based on short and medium results [40]. Tourists consider that an approach that focuses on environmental practices and the form of presentation of ecotourism services may determine their decisions [41], being associated by tourists with destinations with a high value, such as national parks [42].

In the actual context, sustainability in tourism became a driving factor for marketing strategy and is focused on a long relationship between providers and customers [43]. Based on the changes in consumers behavior that are more aware and willing to act on environmental concerns, being "eco-friendly" became a necessity for companies and an unavoidable cost in order to stay competitive on the market [44]. It is an increasing interest for tourist products based on contacts with nature which gives an evident market advantage to ecotourism [45]. In this regard, specific destinations can take advantage of this tendency, which leads to the conclusion that ecotourism must focus on green marketing practices in order to consolidate its image and to remain preferred by the tourists.

\subsection{Romanian Ecotourism and Green Strategies}

Romania has a great potential to become a European poll for ecotourism because of its natural resources and authentic villages located around sensitive ecosystems [46]. Romania is one of the European member countries with a wide range of biogeographical diversity, having on its territory five of the eleven biogeographical areas [47]: "continental, alpine, panonic, pontic (only in Romania and Bulgaria) and steppe (only in Romania)" [48], having in total, "about 800 protected areas that currently cover about $5 \%$ of the country. Most ecotourism destinations are located within or close to protected areas, such as the Danube Delta Biosphere Reserve, or Retezat National Park" [49]. The top 10 ecotourism destinations in Romania include Hațeg-Retezat Land, Romanian Land of the Bison, Zărnești-Stone Mountains, Mara-Cosau-Rooster's Comb, Danube Delta, Sibiu Surroundings, Transylvanian Hills, 
Tusnad Balneums and Surroundings, Dorna Land and Pădurea Craiului Mountains [50]. Moreover, there is a high interest of intern and international tourists for authentic experiences and for a return to nature, which made Romania famous in the last decades at a regional level, attracting the interest of international press and even famous figures [51]. This made the entrepreneurs from natural areas focus on green marketing practices in order to convince guests about the authenticity of their offer.

The switch to green practices from income-oriented behavior came with the promise of higher benefits and led to a misunderstanding of the whole system of ecotourism in some Romanian destinations. Bran region represents an example in this regard. This area proves that only targeting a place as "green" without taking into account the whole meaning of green practices may affect the expectations of tourists and damage the tourist brand on long term. One reason for this situation is the lack of a legal framework in Romania. There is no specific delimitation regarding the position on the market of accommodation units that are suitable to promote as green. This gap in the legislation that is still common in other European countries also, lets natural areas be spoiled and in consequence, ecotourism in these regions tends to transform in mass tourism. In this regard, it became necessary to expose the negative practices which can be translated through "greenwashing" and promote the examples of good practice. This concern pressed the necessity of accreditation which lead to the apparition of several systems of labeling [52]. One such tool was already developed by the European Commission and addresses the hotel industry on a voluntary base: the EU Ecolabel that has as the primary goal to certify the responsible behavior of the accommodation units towards the environment. However, it was demonstrated that there is no significant interest in this certification [53]. The study of Barbulescu et al., published in 2019, reveals that the desire of the hotel management to get the certificate is connected with the managers' level of knowledge about the EU Ecolabel and is linked to their opinion about EU Ecolabel in terms of competitive advantage [54]. In Romania, there is a very low interest in EU Ecolabel certification. At the beginning of 2020, only three Romanian units had this green certification [55].

In Romania, ecotourism is represented by several non-governmental organizations, which are aiming to stimulate the development of sustainable practices, like Tara Dornelor Ecotourism Association, Ecologic Association, Bihor Protected Areas and Sustainable Development Centre, National Association of Ecological and Cultural Rural Tourism in Romania and ECO-Romania Association [56,57]. One of the entities, ECO-Romania Association, has developed an accreditation system for ecotourism accommodation units and tourist routes.

\section{Materials and Methods}

This study presents a descriptive image of the ecotourism accommodation units from Romania that promote as green. The study shows how these establishments use green marketing practices and how their guests perceive the green image. The research is based on primary data, retrieved by the authors from the ECO-Romania Association website, TripAdvisor platform and accommodation units' websites. The results were interpreted using summative Qualitative Content Analysis that involved "counting and comparisons, of specific keywords from the text, followed by the interpretation of the underlying context" [58] without dedicated software.

The study starts from the information posted by ECO-Romanian Association about the units the entity validated through the Eco-Label certification and included in the dedicated section from the website, namely "Accommodation". The information found here and which was introduced in the research include aspects like the names of the units, their location and the website address. The authors relied on the information posted here to avoid the cases in which accommodation units with the same name, but located in other areas, would have been wrongly included in the study.

To analyze the accommodation units' websites, the authors investigated if the Eco-Label provided by ECO-Romania Association is posted on the all webpages of the units and if the content of the homepage is relevant for ecotourist activity - it was considered that the presence of suggestive pictures (i.e., Romanian villages, traditional crafts) and testimonials should be relevant for this step of the 
research. Related pictures may help tourists from the very beginning to realize if the accommodation establishment meets their criteria. In addition, the presence of testimonials completes the first impression based on the pictures and validates the image of the unit. It was also investigated if the websites have the content in other languages except for Romanian in order to make a first image of the market approach. A website with content available only in the local language suggests that the unit addresses mainly to the domestic market, in contrast to the webpages translated in other languages that indicate the orientation to international market.

The summative Qualitative Content Analysis was applied to analyze the content of the unit's description and their reviewers from TripAdvisor platform. The first step consisted of identifying the accounts of the units on the platform and the presence of their description in Romanian or English. For the units presented on TripAdvisor with an available description, the authors analyzed the content provided by the accommodation establishment taking into account the presence of keywords related to the definitions of green marketing and ecotourism. The keywords were included in one of the following four main categories: activities (i.e., walking, bike rental, tours), unit description (i.e., village, authentic, local), local food (e.g., traditional, fresh, home-made) and surroundings (i.e., architecture, National Park, quiet, wildlife). In the case of each description, the authors identified the keywords that are related to ecotourism and green marketing (the Romanian terms were translated into English) and added them in each category, according to their meaning. Based on the limited number of the units with an available description on the platform, the keywords screening from the description of the units was made without a specific tool. For the summative Qualitative Content Analysis of the comments of the guests posted on TripAdvisor, the authors used the same algorithm for including the keywords in the four categories as in the case of units' descriptions. In this case, the screening method was different. The authors used the online function of the platform that identifies automatically the most common keywords and phrases, namely popular mentions.

Based on the lack of legal framework in Romania regarding green labeling in tourism accommodation, the authors choose for the analysis the data published by ECO-Romania Association that developed an accreditation system recognized by the European Parliament in the paper entitled Research for TRAN Committee-European Tourism Labeling, published in 2018. The accreditation process provided by the ECO-Romania is voluntary-based and implies a contra-cost evaluation [59]. In this regard, the authors considered this labeling system the most appropriate for the article.

The main purpose of the study is to obtain a detailed description of the online presence of ecotourism accommodation units that opted for the Eco-label provided by the ECO-Romania Association. The period of online analysis was February 2020-April 2020. In order to accomplish the goal of the study, the authors considered three main objectives that help them to have a complex overview of ecotourism accommodation units that use green marketing, like (i) the analysis of the accommodation unit's website, (ii) the units' description on TripAdvisor and (iii) the feedback of the guests on TripAdvisor.

The authors developed the methodology used for the research following the characteristics of the primary data investigated and took into account the definitions of green marketing, ecotourism activities and the characteristics of TripAdvisor platform. The authors focused on aspects like and derived from fauna, flora, cultural sites, educational accents, environmental issues and local community benefits [60]. The methods refer to online analyses made on the ECO-Romania website, on the accommodation units' website and also on TripAdvisor platform, having the same structure and list of items for both unit's description and guests' perception. The research instrument used consisted of the following observation lists (Table 1): 
Table 1. The objectives of the study.

\begin{tabular}{|c|c|c|}
\hline & Dbjectives of the Research & Aspects Considered in the Research \\
\hline (I) & $\begin{array}{l}\text { The analysis of the } \\
\text { accommodation } \\
\text { unit's website }\end{array}$ & $\begin{array}{l}\text { - } \quad \text { the presence of the Eco Label provided by ECO-Romania Association } \\
\text { - } \quad \text { the content of the homepage (suggestive pictures, testimonials) } \\
\text { - } \quad \text { the linguistic version of the website } \\
\text { mapping of the units }\end{array}$ \\
\hline (II) & $\begin{array}{l}\text { The unit's description } \\
\text { on TripAdvisor }\end{array}$ & $\begin{array}{l}\text { - } \quad \text { the presence of the units on TripAdvisor } \\
\text { - } \quad \text { the presence of the description field } \\
\text { the analysis of the description provided by the unit in terms of } \\
\text { green marketing }\end{array}$ \\
\hline (III) & $\begin{array}{l}\text { The feedback of the guests } \\
\text { on TripAdvisor }\end{array}$ & $\begin{array}{l}\text { - } \quad \text { the presence of the comments } \\
\text { - } \quad \text { number of comments } \\
\text { - } \quad \text { the analysis of the comments in terms of green marketing }\end{array}$ \\
\hline
\end{tabular}

Source: Developed by the authors.

In order to analyze the green image of the units in the online environment and the guests' perception in this regard, the authors decided to create four main categories to include the most common terms found both in the description of the units and in the guests' reviews posted on TripAdvisor. The four categories were designed considering the definitions of green marketing and ecotourism and included activities in nature (i.e., biking, bird watching), unit description (using words like quiet, wood), local food (i.e., traditional, homemade) and surroundings (description like mountain village). The last category was divided into four secondary categories: touristic monuments, flora and fauna, geography/localization and atmosphere.

To be able to compare the results and to keep the coherency, the authors used the same selection algorithm for both unit's description and guests' reviews and to assure the data accuracy, it was used the online function powered by TripAdvisor, named popular mentions. The authors consider this approach relevant for the research because it gives a real insight to stakeholders in ecotourism, relying on public data that are available to the general public.

\section{Results}

\subsection{The Analysis of the Accommodation Unit's Website}

At the date of research, 20 accommodation units were validated by ECO-Romania, with the following profile: 15 pensions, two hotels, one cottage, one camping/hostel and one resort, located in the following counties: Brașov (3), Suceava (3), Hunedoara (3), Bihor (2), Maramureș (2), Sibiu (2), Tulcea (2), Bistrița-Năsăud (1), Covasna (1) and Harghita (1). The units are located in villages (13), or small towns (7) and all of them are located near natural areas (Figure 1). From the 20 units, only eight units have the label provided by ECO Romania Association visible on the homepage.

The authors also noticed that the websites have only simple functions, being created as descriptive pages, without interaction with the users. Only four units have posted testimonials, the others resuming at a more impersonal presentation. In general, the units are presented as being dedicated to ecotourism, describing the available options to spend time in nature, delimiting from mass tourism and promoting their homemade products also (food, handicrafts, souvenirs). However, in two cases the accommodation units also post offers for teambuilding and private or corporate events. 


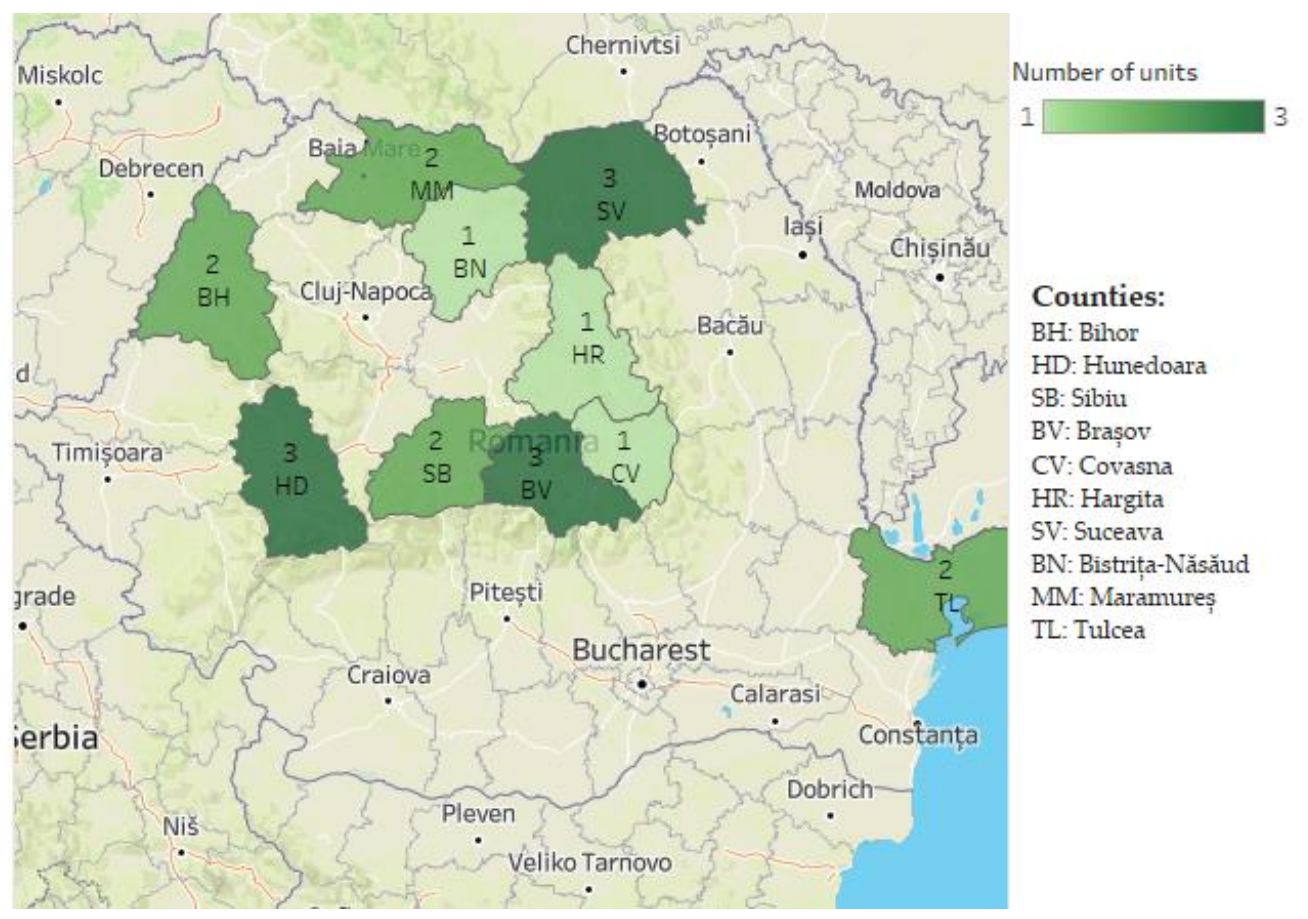

Figure 1. The mapping of the ecotourism units. Source: developed by the authors in Tableau Public software, based on the ECO-Romania data.

The authors also analyzed the design of the homepage and the pictures presented on the websites, considering indicators as architecture details in images, village illustration, traditions and popular art. The investigation revealed that from the total of 20 units, 18 had posted suggestive images for ecotourism on their website, indicating traditional activities and tourism activities in nature. In addition, 16 units have an English version of the website and ten units have additional linguistic versions, the information being available in German, French, Russian, Hungarian and Slovakian.

\subsection{The Units' Description on TripAdvisor}

From the total of 20 units, 16 had an account on TripAdvisor at the moment of the study, and from these, two had no description on the platform, and three had no comment posted by the guests. There remained for this part of the study 11 units to be investigated. At this stage of the study, the authors analyzed every description posted by the units and connected it with the definitions of green marketing and ecotourism. The text analyses revealed that all 11 units have at least one word or phrase that suggests green marketing. The units promote like being traditional and cozy residences where the guests can spend their time in nature transposing them in an atmosphere specific to decades ago, where tourists can practice specific activities, like gardening, riding, cooking or learning handcrafts. Their description also contains details about touristic monuments, highlighting aspects of national Parks and historical issues (Table 2). According to their description posted on TripAdvisor, accommodation units categorized themselves with the following attributes: mountain view, family, quaint, charming, great view, historic hotel. 
Table 2. The analysis of the accommodation units' description.

\begin{tabular}{|c|c|c|}
\hline \multicolumn{2}{|c|}{ Activities } & $\begin{array}{c}\text { Gardening, bike rental, eco-tours, tours to historic sites, cartridge riding, } \\
\text { animal feeding, walking, fishing, boat trip, baking and } \\
\text { cooking, handicrafts. }\end{array}$ \\
\hline \multicolumn{2}{|c|}{ Unit Description } & $\begin{array}{l}\text { Simple, village museum, eco-friendly, wood, cozy residence, } \\
\text { authenticity, relaxation, local lifestyle, family. }\end{array}$ \\
\hline \multicolumn{2}{|c|}{ Local Food } & $\begin{array}{l}\text { traditional Romanian food, Saxon dishes, daily fresh food, traditional, } \\
\text { home-made receipts. }\end{array}$ \\
\hline \multirow{4}{*}{ Surroundings } & $\begin{array}{c}\text { Touristic } \\
\text { Monuments }\end{array}$ & $\begin{array}{l}\text { The fortress of Ponor, historic site, wild beauty of Natura } 2000 \\
\text { Reservations, saxon fortified churches, UNESCO, Halmyris Monastery, } \\
\text { Dracula's castle, Densus church, roman ruins of } \\
\text { Sarmisegetuza, architecture. }\end{array}$ \\
\hline & Flora \& Fauna & - \\
\hline & $\begin{array}{l}\text { Geography/ } \\
\text { Localization }\end{array}$ & $\begin{array}{l}\text { Romanian Carpathians Mountain, village, Piatra Craiului National Park, } \\
\text { Pietroasa, the Retezat Mountains, Country of Hateg, Viseu de Sus, wild } \\
\text { hills, Uzlina island, Forests, Danube Delta, Transylvanian landscape. }\end{array}$ \\
\hline & Atmosphere & quiet, childhood, authentic, life half a century ago, cozy, culture. \\
\hline
\end{tabular}

Source: developed by the authors, based on the units' description on TripAdvisor.

The analysis revealed that the units focused more on describing touristic monuments and giving details about the local geography and less on the atmosphere and unit description. They also avoided specifying details about flora and fauna available in the area.

\subsection{The Feedback of the Guests on TripAdvisor}

In order to investigate if the guests also perceive the green marketing initiatives of the units, the authors wanted to see if their comments on TripAdvisor include repetitively words or phrases that have a direct link with the green marketing activities. There were took into consideration the most common repeated words presented in the guests' reviews. Out of the total of 20 units, there were excluded those that did not have an account on TripAdvisor and those that did not have reviews. There remained 11 units for the study, with a total of 648 comments posted on TripAdvisor. The comments were available both in the English and Romanian languages. In order to assure a comparative analysis of the content, we translated first the most common terms and phrases from Romanian to English. After this step we included the terms in the four main categories, depending on their meaning.

The investigation revealed a more balanced interest of the guests for all categories, with the highest interest in geography/localization details. Tourists are also concerned about flora and fauna available in the area, often mentioning the possibility to observe the wildlife. The local food is also a subject of interest, being mentioned the quality of dishes and the traditional recipes (Table 3).

Table 3. The analysis of guests' comments on TripAdvisor.

\begin{tabular}{|c|c|c|}
\hline \multicolumn{2}{|c|}{ Activities } & Hiking, Catamaran, Guide, boat trip, birds watching; \\
\hline \multicolumn{2}{|c|}{ Unit description } & $\begin{array}{l}\text { Hide, quiet place, yard, tent, camping, old house, beautiful view, } \\
\text { cottage, location is excellent, beautiful place, very nice place. }\end{array}$ \\
\hline \multicolumn{2}{|c|}{ Local food } & $\begin{array}{c}\text { traditional food, meal, tasty food, apple juice, traditional dishes, } \\
\text { homemade, food quality. }\end{array}$ \\
\hline \multirow{4}{*}{ Surroundings } & $\begin{array}{l}\text { Touristic } \\
\text { monuments }\end{array}$ & painted monasteries, fortified church, Saxon village. \\
\hline & Flora \& Fauna & local wildlife, bear, nature, surroundings, fish, birds, wild beach. \\
\hline & $\begin{array}{l}\text { Geography/ } \\
\text { localization }\end{array}$ & $\begin{array}{c}\text { village, great history, mountains, Transylvania, lakes, channels, delta, } \\
\text { Danube, river. }\end{array}$ \\
\hline & Atmosphere & piece of heaven, peace, relaxing weekend, unique place. \\
\hline
\end{tabular}

Source: developed by the authors, based on the guests' reviews posted on TripAdvisor. 
Tourists are more interested in activities that can be carried out in nature and that give them a complex experience. Guests describe each visit like an elaborate trip that includes a variety of activities in nature that are connected to the green image of the units.

\section{Discussion}

Tourists expectations have changed lately, and their requirements imply now a more sustainable way to do business. A green-oriented branding became the new normal for the guests, especially for the young ones who want to find a connection with nature during their holiday. By developing the ECO-label accreditation at the national level, the Romanian ecotourism may obtain a decisive advantage on the market.

Romanian ecotourism is a sensitive field that needs national legislation to protect natural resources. The Romanian potential and the progress made in the field in the last decades highlight the need for greater involvement of the authorities in this regard. This study shows that even though there is a lack of legislative framework, tourism association and accommodation units understand the importance of green label and necessity of such an accreditation that certify their activity. The interest in providing a green label accreditation provided by ECO Romanian Association proves that the specialists in the field are aware of the need for a set of rules and recommendations that could bring added value on the market.

This research found that the connection between a correct green marketing approach that implies a full description of the units and a suggestive website can create a complex image of the accommodation units that can be noticed in the guests comments on TripAdvisor platform. The study shows the interest from the accommodation units to present their offer and activity as green and to find a solution that certify their behavior. The total number of 20 units that were present at the moment of the research on the ECO Romanian association website may have two meanings. On the one hand, the whole process is at the beginning, and it was not fully adopted at the national level. On the other hand, it shows that the association is not focused on quantity, which gives credibility to the whole process. Moreover, the fact that accreditation is on a voluntary base and implies the payment of a fee and the compliance with a set of rules reinforces the idea that the representatives of the units appreciate the importance of green label. The results indicate that almost half of the units understand the role of the eco-label and post it in a visible place on their website. They also present a green image in the online environment through suggestive images promoted on their website, which means that the units interested in certifying are already concern about green practices and have integrated green marketing in their daily business.

The results of the study indicate that ecotourism providers use green marketing to promote their products on their website and TripAdvisor platform. They describe their business following green marketing definition and try to offer a comprehensive description of their activity. In addition, tourists show a high interest in activities in nature and appreciate authentic aspects from the destination. This means that green marketing is fully understood by the accommodation units and is perceived by the guests.

From the description posted on TripAdvisor and the interpretation of the comments, the authors can conclude that both unit's representatives and tourists are concerned about green marketing and take advantage of it. However, there is a difference between the unit's perception of some details and the guests' perspective in this regard. Results show that tourists are interested in a more complex and authentic experience and would like to observe wildlife—an issue that was not identified by the unit's representatives as necessary.

Based on the importance of ecotourism for Romania and the need for preservation of natural tourist resources, the authors consider that green marketing practices should be applied on a larger scale. The authors show in this article that some stakeholders already accepted accreditation in the field. In this context, Eco-label could be implemented by other units also and can become a permanent component of green marketing strategy. However, the present study has several limitations, and its results cannot be generalized at the national level. The small number of the units included and restricting the approach 
only to the accreditation system provided by ECO-Romania Association give a local description of the green marketing strategy of the Romanian ecotourist accommodation establishment. In addition, the geographical limitation of the units, which refers only to the 10 Romanian counties out of the 42 , asks for more research in this area. Another limitation of the study is that the methodology included only summative Qualitative Content Analysis and qualitative website analysis. In order to have a more in-depth view about the green marketing strategies in ecotourist field, this study should be completed by other research based on several interviews applied among the essential stakeholders in the field: units representatives, ecotourist and marketing associations, tourists and National Authorities in the area. In this regard, the research team wants to continue the study and go into more detail about the accreditation system, with a focus on the accreditation experience of the ECO-Romania Association in order to find more about this process from the accommodation units' perspective. The authors intend to complete this study with qualitative research based on a semi-structured interview to investigate the perception of the stakeholders about green marketing. This approach aims to give a more comprehensive overview of the need for green practices in ecotourism and to formulate a set of recommendations for the authorities in order to facilitate the accreditation system at the national level. In this way, Romania would succeed to develop a green brand recognized internationally.

\section{Conclusions}

This article presents the green marketing presence in Romanian ecotourism, taking into account how the accommodation units choose to describe their activity online and if the guests also perceive the green practices of the units. The study starts from the accreditation system provided by ECO-Romania Association that validates the status of ecotourist units and which was chosen by the authors based on its recognition by the European Parliament as a valid accreditation system.

The results stress the importance of developing an accreditation system for ecotourism activities at the national level or the necessity of expanding the existing one to all the regions from Romania. The lack of interest from the authorities in the tourism field in developing a national accreditation system widely adopted by the units with interest in this regard showed that the actual situation did not stop the establishments from finding a solution. The existence of Eco-label provided by the ECO-Romania Associations and the attention of the units from ten Romanian counties provide that the representatives from ecotourism are aware of the new demand trends and try to meet the requirements of the guests. The unit's representatives know the new focus of the tourists on activities in nature and their desire to have a full experience during the holiday. In this context, the managers present their online activity based on green marketing practices and try to describe in detail their ecotourist activity.

The fact the tourists perceive the message of the accommodation units regarding green marketing strategies shows that even in a context in which the accreditation system is on a voluntary basis, the stakeholders in the field understand the importance of green practices and make efforts in order to have a proper online presence. In this context, authorities should focus more on developing together with the stakeholders in tourism green marketing strategies, including a national accreditation system for ecotourism. In this way, the Romanian destinations could become more attractive to the international tourist.

Author Contributions: P.N. was responsible for methodology and results interpretation, A.-C.A. was responsible for literature review, results interpretation and discussions part of the paper and A.D. assured the mapping output and conclusion section. All three authors contributed equally to the introduction, verification of bibliography and writing of metadata All authors have read and agreed to the published version of the manuscript.

Funding: This work was cofinanced from the European Social Fund through Operational Programme Human Capital 2014-2020, project number POCU/380/6/13/125015" Development of entrepreneurial skills for doctoral students and postdoctoral researchers in the field of economic sciences".

Conflicts of Interest: The authors declare no conflict of interest. 


\section{References}

1. Tilikidou, I.; Delistavrou, A. Preferring green and rejecting "unethical” hotels. Euro. Med. J. Bus. 2015, 10, 285-296. [CrossRef]

2. Chan, E.S. Gap analysis of green hotel marketing. Int. J. Contemp. Hosp. Manag. 2013, 25, 1017-1048. [CrossRef]

3. Wheeler, M. Tourism marketing ethics: An introduction. Int. Mark. Rev. 1995, 2, 38-49. [CrossRef]

4. Insch, A. Conceptualization and anatomy of green destination brands. Int. J. Cult. Hosp. Res. 2011, 5, 282-290. [CrossRef]

5. Wu, H.-C.; Wei, C.-F.; Tseng, L.-Y.; Cheng, C.-C. What drives green brand switching behavior? Mark. Intell. Plan. 2018, 36, 694-708. [CrossRef]

6. Wu, H.-C.; Cheng, C.-C.; Ai, C.-H. What drives green experiential loyalty towards green restaurants? Tour. Rev. 2019, 1-20. [CrossRef]

7. Lu, L.; Bock, D.; Joseph, M. Green marketing: What the millennials buyjournal of business strategy. J. Bus. Ethics 2013, 34, 3-10. [CrossRef]

8. Sirimanne, E. Going green: Sustainability in Singapore; Euromonitor International: London, UK, 2019.

9. Pagliacci, M.; Manolică, A.; Roman, T.; Boldureanu, G. The consumers of green products. The case of romanian moldavia counties. Amfiteatru Econ. 2019, 21, 830-844.

10. Sarkar, J.G.; Sarkar, A.; Yadav, R. Brand it green: Young consumers' brand attitudes and purchase intentions toward green brand advertising appeals. Young Consum. 2019, 20, 190-207. [CrossRef]

11. Dabija, D.C.; Bejan, B.; Grant, D. The impact of consumer green behaviour on green loyalty among retail formats: A romanian case study. Morav. Geogr. Rep. 2018, 26, 173-185. [CrossRef]

12. Martínez, P. Customer loyalty: Exploring its antecedents from a green marketing perspective. Int. J. Contemp. Hosp. Manag. 2018. [CrossRef]

13. Leslie, D. The Consumers of Tourism, in Responsible Tourism: Concepts. Theory and Practice; Leslie, D., Ed.; CABI: Manchester, UK, 2012; pp. 54-71.

14. Yadav, R.; Dokania, A.K.; Pathak, G.S. The influence of green marketing functions in building corporate image Evidences from hospitality industry in a developing nation. Int. J. Contemp. Hosp. Manag. 2016, 28, 2178-2196. [CrossRef]

15. Kumar, P. Green marketing innovations in small Indian firms. World J. Entrep. Manag. Sustain. Dev. 2015, 11, 176-190. [CrossRef]

16. Dean, T.J.; Pacheco, D.F. Green marketing: A strategic balancing act for creating value. J. Bus. Strategy 2014, 35, 14-22. [CrossRef]

17. Narula, S.A.; Desore, A. Framing green consumer behaviour research: Opportunities and challenges. Soc. Responsib. J. 2016, 12, 1-22. [CrossRef]

18. Kirchoff, J.F.; Koch, C.; Nichols, B.S. Stakeholder perceptions of green marketing: The effect of demand and supply integration. Int. J. Phys. Distrib. Logist. Manag. 2011, 41, 684-696. [CrossRef]

19. Papadopoulos, I.; Karagouni, G.; Trigkas, M.; Platogianni, E. Green marketing the case of Greece in certified and sustainably managed timber products. Euro. Med. J. Bus. 2010, 5, 166-190. [CrossRef]

20. Kumar, P. State of green marketing research over 25 years (1990-2014) Literature survey and classification. Mark. Intell. Plan. 2016, 34, 137-158. [CrossRef]

21. Dabija, D.C.; Pop, C.M. Green marketing-Factor of competitiveness in retailing. Environ. Eng. Manag. J. 2013, 12, 393-400. [CrossRef]

22. Rosenbaum, M.S.; Wong, I.A. Green marketing programs as strategic initiatives in hospitality. J. Serv. Mark. 2015, 29, 81-92. [CrossRef]

23. Euromonitor Eco worriers: Global green behaviour. Euromonitor Int. 2015.

24. Dinu, V. Food safety in the context of the European Union. Amfiteatru Econ. 2018, 20, 5-7. [CrossRef]

25. Fatoki, O. Green marketing orientation and environmental and social performance of hospitality firms in south Africa. Found. Manag. 2019, 11, 277-290. [CrossRef]

26. Líšková, Z.D.; Cudlínová, E.; Pártlová, P.; Petr, D. Importance of green marketing and its potential. Visegr. J. Bioeconomy Sustain. Dev. 2016, 5, 61-64. [CrossRef]

27. Govender, J.P.; Govender, T.L. The influence of green marketing on consumer purchase behavior. Environ. Econ. 2016, 7, 77-85. [CrossRef] 
28. Vilkaite-Vaitone, N.; Skackauskiene, I. Green marketing orientation: Evolution, conceptualization and potential benefits. Open Econ. 2019, 2, 53-62. [CrossRef]

29. Singh, S.; Dash, T.R.; Vashko, I. Tourism, ecotourism and sport tourism: The framework for certification. Mark. Intell. Plan. 2015, 34, 236-255. [CrossRef]

30. Dorobanţu, M.R.; Nistoreanu, P. Hospitality-A component of Romanian rural tourism products. Cactus Tour. J. 2012, 3, 17-23.

31. UNWTO. Ecotourism and Protected Areas. 2020. Available online: https://www.unwto.org/sustainabledevelopment/ecotourism-and-protected-areas (accessed on 15 February 2020).

32. Fennell, D.A.; Ecotourism. International Encyclopedia of Human Geography; Department of Tourism and Environment, Brock University: St. Catharines, ON, Canada, 2020; pp. 51-55. [CrossRef]

33. Gheorghe, A.; Pârvu, F. Aspects regarding green economy's. Bus. Excell. Manag. 2016, 6, 21-35.

34. Wang, C.-C.; Cater, C. Ecotourism as a Sustainable Recovery Tool after an Earthquake. In Tourism Crisis and Disaster Management; Ritchie, B., Campiranon, K., Eds.; CABI: Cambridge, UK, 2015; pp. 209-226.

35. Heyne, L.A.; Camacho, J.V. Revitalizing rural communities in Costa Rica through sustainable tourism. In Tourism, Health, Wellbeing and Protected Areas; Azara, I., Eleni, M., Federico, N., Derrick, T., Alan, C., Eds.; CABI: Manchester, UK, 2018; pp. 149-166.

36. Rotherham, I.D. Emerging concepts and case studies of eco-cultural tourism. In Cultural Tourism; Raj, R., Griffin, K., Morpeth, N., Eds.; CABI: Manchester, UK, 2013; pp. 74-89.

37. Stronza, A.; Hunt, C.; Fitzgerald, L. Ecotourism for Conservation? Annu. Rev. Environ. Resour. 2019, 44, 229-253. [CrossRef]

38. Ayachi, H.; Jaouadi, S. Problems and perspective of ecotourism in the Island of Farasan an empirical study based on survey data. Soc. Bus. Rev. 2017, 12, 235-251. [CrossRef]

39. Farrell, H.; Russell, S. Rural Tourism in Research Themes for Tourism; Robinson, P., Heitmann, S., Dieke, P., Eds.; CABI: Manchester, UK, 2011; pp. 100-113.

40. Dimitriou, C.K. From theory to practice of ecotourism: Major obstacles that stand in the way and best practices that lead to success. Eur. J. Tour. Hosp. Recreat. 2017, 8, 26-37. [CrossRef]

41. Jamrozy, U.; Lawonk, K. The multiple dimensions of consumption values in ecotourism. Int. J. Cult. Tour. Hosp. Res. 2017, 11, 18-34. [CrossRef]

42. Jun, K.S. The structural relationships of destination image, awareness, uniqueness and destination loyalty in periurban ecotourism destination. Eur. J. Tour. Hosp. Recreat. 2017, 7, 212-225. [CrossRef]

43. Cuculeski, N.; Petrovska, I.; Cuculeski, V. Sustainable marketing and consumers' preferences in tourism. Eur. J. Tour. Hosp. Recreat. 2016, 7, 84-90. [CrossRef]

44. Lewandowska, A.; Witczak, J.; Kurczewski, P. Green marketing today-A mix of trust, consumer participation and life cycle thinking. Management 2017, 21, 28-48. [CrossRef]

45. Barwicka, K.; Olearnik, J. The behaviour of tourism market participants in the context of the development of ecotourism. Manag. Sci. 2019, 24, 18-25. [CrossRef]

46. Ban, O.I.; Iacobaş, P.; Nedelea, A.M. Marketing research regarding tourism business readiness for eco-label achievement. Ecoforum 2016, 5, 224-234.

47. Neacsu, A.; Dodu, P. The development of ecotourism in protected areas study case: Comana national park. Rom. Econ. Bus. Rev. 2019, 14, 74-85.

48. Ursu, A.; Stoleriu, C.C.; Ion, C.; Jitariu, V.; Enea, A. Romanian Natura 2000 Network: Evaluation of the threats and pressures through the corine land cover dataset. Remote. Sens. 2020, 12, 75. [CrossRef]

49. Tisca, I.A.; Istrat, N.; Dumitrescu, C.D.; Cornu, G. Management of Sustainable Development in Ecotourism; Case Study Romania, in 3rd Global Conference on Business, Economics, Management and Tourism; CABI: Rome, Italy, 2015. [CrossRef]

50. Bejinaru, R.; Cozorici, A.N. Challenges for Romanian ecotourism destinations. J. Tour. Stud. Res. Tour. 2016, $22,1-8$.

51. Avram, D. Trends of tourist demand in Romania. Positioning of rural tourism among the tourist preferences. Cactus Tour. J. 2017, 15, 14-25.

52. Mazilu, M.; Marinescu, R.; Gheorgheci, S. Aspects Regarding the Romanian Certification in Ecotourism Destinations; Economy Series; Annals of the Constantin Brâncuşi, University of Târgu Jiu: Târgu Jiu, Romania, 2017; Volume 3, pp. 109-116. 
53. Dinu, V.; Schileru, I.; Atanase, A. Attitude of Romanian consumers related to products' ecological labelling. Amfiteatru Econ. 2012, 14, 8-24.

54. Barbulescu, A.; Moraru, A.D.; Duhnea, C. Ecolabelling in the Romanian seaside hotel industry-Marketing considerations, financial constraints, perspectives. Sustainability 2019, 11, 265. [CrossRef]

55. Weston, R.; Grebenar, A.; Lawler, M.; Herbert, H.; Sillence, G.; Balas, M.; Denman, R.; Pezzano, A.; Reiner, K. Research for TRAN Committee European Tourism Labelling. In Proceedings of the European Parliament; Policy Department for Structural and Cohesion Policies: Brussels, Belgium, 2018.

56. Candrea, A.N.; Herţanu, A. Developing Ecotourism Destinations in Romania; A Case Study Approach; Bulletin of the Transilvania University of Braşov: Braşov, Romania, 2015; pp. 163-174.

57. AER. Association of Ecotourism in Romania. 2020. Available online: https://www.asociatiaaer.ro/certificare/ (accessed on 20 February 2020).

58. Hsieh, H.F.; Shannon, S.R. Three Approaches to qualitative content analysis. Qual. Health Res. $2005,15$. [CrossRef]

59. Eco Romania. 2011. Available online: https://www.eco-romania.ro/ecoturism/despre-aer/ (accessed on 20 February 2020).

60. Voicu, M.C. Aspects regarding the promotion of ecotourism to consumers. Challenges of the Knowledge Society. Econ. Sci. 2018, 12, 963-968.

(C) 2020 by the authors. Licensee MDPI, Basel, Switzerland. This article is an open access article distributed under the terms and conditions of the Creative Commons Attribution (CC BY) license (http://creativecommons.org/licenses/by/4.0/). 